\title{
Age, growth and reproduction of the lizard fish Saurida undosquamis from the Gulf of Suez, Red Sea, Egypt
}

\author{
Salah G. El-Etreby ${ }^{1}$; Azza A. El-Ganainy ${ }^{2}$; Mahmoud A. Saber ${ }^{1}$; Magdy A. El- \\ Alwany $^{2}$ and Al-Azab A. El-bokhty ${ }^{2}$ \\ 1- Marine Science Department, Faculty of Science, Suez Canal University \\ 2- Fisheries Division, National Institute of Oceanography and Fisheries
}

\section{ABSTRACT}

The lizard fish Saurida undosquamis represents one of the most commercial fish in the Gulf of Suez. The growth and reproductive biology of the species were studied. The age was determined from otolith readings of the collected specimens from the Attaka Harbor through the period from September 2011 to April 2012. The results show that the life span of the sampled fish was seven years. The estimated von Bertalanffy growth equation was $\mathrm{L}_{\mathrm{t}}=51.252\left(1-\mathrm{e}^{-0.131(\mathrm{t}+1.45)}\right)$, the calculated lengthweight relationship was $\mathrm{W}=0.004 \mathrm{~L}^{3.107}$. Seasonally distribution of gonado-somatic index (GSI) values showed that the main peak of GSI was in spring. The results of gonad development stages show that, Saurida undosquamis is a synchronous spawner. The size at which $50 \%$ of fishes are mature was $15.0 \mathrm{~cm}$ for males and $15.5 \mathrm{~cm}$ for females, which indicates that all individuals over one year of age were sexually mature. The results indicated that juvenile individuals are one of the targets of the fishery and the protection of the juveniles is probably the key factor for the sustainability of the resources.

Keywords: Age, growth, reproduction, Saurida undosquamis, Gulf Suez, Red Sea.

\section{INTRODUCTION}

The lizard fishes are worm-water fishes widely distributed in the Indopacific regions. They are the most commercially important species in the trawl fishery of the Gulf of Suez. The lizard fishes in the Gulf of Suez are represented by four species namely Saurida undosquamis, Trachinocephalus myops, Synodus variegates and Synodus indicus of which S. undosquamis is the most abundant species; comprise about $95 \%$ of the lizard fish catch (El-Ganainy, 2003). The landings of the lizard fishes constitute $31 \%$ of the total trawl catch in the Gulf. As one of the most important demersal fishes, the stock of the lizard fishes in the Gulf of Suez and Red Sea has experienced heavy exploitation (El-Ganainy 1992, 1997, 2003 and 2004).

The brush tooth lizard fish Saurida undosquamis is very abundant in the northern part of the Gulf of Suez and is usually fished at depths between 20-70 m and found mostly over sandy or muddy bottoms (Youssif, 2004). It is reported that the maximum size of this fish is about $50 \mathrm{~cm}$ (El-Ganainy (1997) however, in landings, the common size range was between 15 and $35 \mathrm{~cm}$.

The reproductive biology and population structure of $S$. undosquamis were investigated by Shenouda (1976) and El Ganainy (1997 and 2004) in the Red Sea; Sanders \& kedidi (1984) and El-Ganainy (1992, and 2003); Amin et al. (2007) and El Halfawy et al. (2007) in the Gulf of Suez. The species was the subject of many studies in the Indo-Pacific region, of which are: Xu et al. (1994); Pauly \& Gayanilo (1996); Letourneur et al.(1998); Abdallah (2002); Yoneda et al. (2002); Chen (2003); Jianguo et al. (2011); Wang et al.(2o11); Metar et al. (2011); Xuehui et al. (2012); and 
Kadhorsha et al. (2013). It was studied in the Mediterranean waters also by Faltas (1993); Ismen (2003); El-Greisy (2005); Cicek et al. (2006); Gokce et al.(2007); Manasirli et al.(2011); Cicek and Avsar (2011) and Edelist (2012).

The assessment of demersal fish like Lizard fish stock and the establishment of fishery management guidelines are urgently and continuously needed in the Gulf of Suez. The purpose of this study is to determine the age, growth, and the reproductive biology of $S$. undosquamis, in order to help in its proper management.

\section{MATERIAL AND METHODS}

\section{Study area:}

The Gulf of Suez extends about $250 \mathrm{~km}$ from Suez in the north (Lat. 29 $56^{\prime} \mathrm{N}$ ) to Shadwan Island in the south (Lat. $27^{\circ} 36^{\prime} \mathrm{N}$ ). Its width varies between 20 and 40 $\mathrm{km}$, and its depth throughout its axis is fairly constant with a mean depth of $45 \mathrm{~m}$ (Fig.1). Three main fishing methods are operating in the Gulf; trawl, purse-seine and artisanal fisheries; especially long and hand lines.

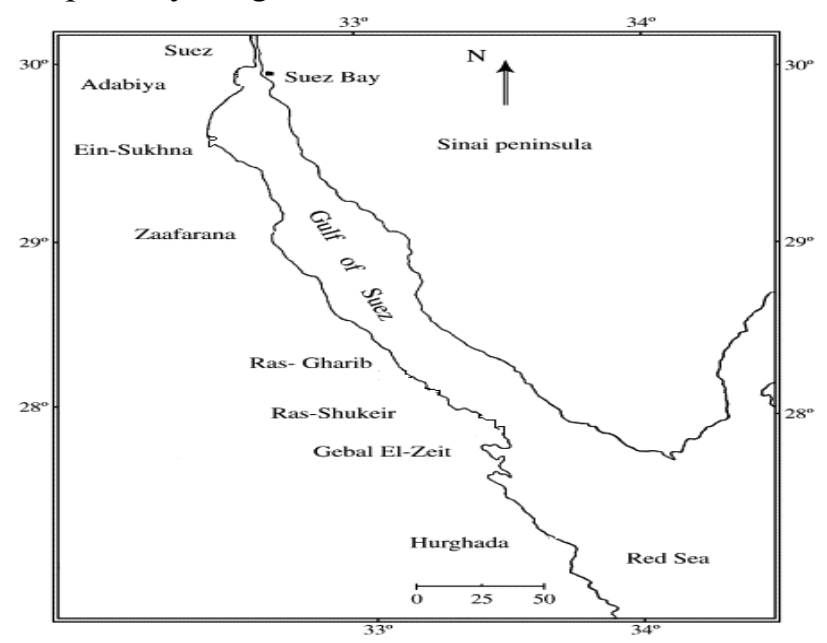

Fig. 1: Map of the study area

\section{Collection of data:}

Data of the catch of the lizard fishes were studied from the records of the General Authority of Fish Resources Development (GAFRD).

Monthly random samples (965 fish from 10.5- $36.1 \mathrm{~cm} \mathrm{TL}$ ) were collected from the Attaka Harbor during the period from October 2011 to September 2012. The total length to the nearest millimeter and total weight to the nearest $0.1 \mathrm{~g}$ was measured. Sex, maturity stage and gonad weight for each sampled specimen were recorded. The length frequency distributions were determined at $1.0 \mathrm{~cm}$ length intervals.

\section{Data analysis:}

Age was determined by counting the annual rings on the otolith of $S$. undosquamis as the otoliths contain concentric growth band pairs, including translucent and opaque bands. The growth band pairs on the otoliths were examined under a binuclear stereomicroscope. The assigned ages at each length group-were used for the estimation of the growth parameters $\left(\mathrm{L}_{\infty}, \mathrm{K}\right.$ and $\mathrm{t}_{\mathrm{o}}$ ) according to von Bertalanffy (1938) growth formula:

$$
\mathrm{L}_{\mathrm{t}}=\mathrm{L}_{\infty}\left(1-\mathrm{e}^{-\mathrm{K}(\mathrm{t}-\mathrm{t})}\right)
$$

Where $\mathrm{L}_{\infty}$ is the asymptotic length in $\mathrm{cm}, \mathrm{K}$ is the growth coefficient and $\mathrm{t}_{0}$ is the length at age 0 . 
The spawning season was determined by estimating the average seasonal gonado-somatic index (GSI) for both male and female as a percentage of the gonad weight to the total body weight of the fish.

$$
\mathrm{GSI}=\mathrm{Gwt} / \mathrm{Twt} \times 100
$$

The seasonal variations of different maturity stages were determined for each individual and classified into six maturity stages according to the scale of Gunderson's (1993) with some modifications. Length at first sexual maturity Lm50 was estimated according to king (1995) for each length group.

\section{RESULTS}

\section{Statistics of catch and effort:}

The annual total trawl catch and lizardfish catch (ton) landed at Atakka Harbor during the last twelve years from fishing season 2000/2001 to 2011/2012 (Fig. 2) showed that the lizard fish catch fluctuated between a maximum value of 2014.48 ton and a minimum value of 771.58 ton representing an average of $28.7 \%$ of the total trawl catch. The lizardfish catch per landing fluctuates between the highest value (1174 Kg/landing) recorded during the fishing season (2011/2012) and the lowest value $(365 \mathrm{Kg} / \mathrm{landing})$ recorded during the fishing seasons $(2004 / 2005)$, represented graphically in Fig (3).

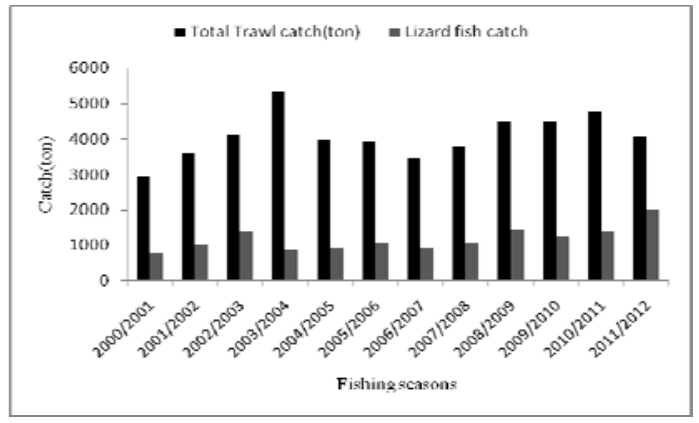

Fig. 2: Seasonal total trawl catch and lizard fish catch in the Gulf of Suez during the fishing seasons; 2000/2001 to 2011/2012.

\section{Length-Weight Relationship:}

The total length of Saurida undosquamis ranged from 10.2 to $36.1 \mathrm{~cm}$ with an average of $18.23 \pm 3.40$ while the total weights ranged from 7 to $304 \mathrm{~g}$ with an average of $43.91 \pm 32.2$.

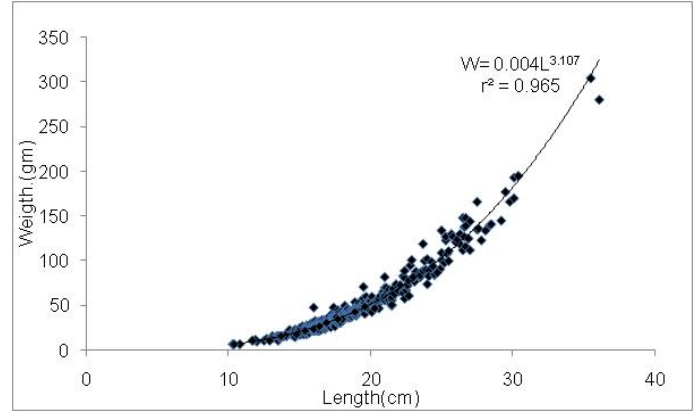

Fig. 4: length-weight relationship for combined sexes of Saurida undosqumis. 
The result of the length weight relationship (Fig. 4) was $\mathrm{W}=0.004 \mathrm{~L}^{3.107}$ (ANOVA, $F=17285.28, P<1.39)$ by: $\left(\mathrm{r}^{2}=0.965, \mathrm{SEa}=0.247, \mathrm{SEb}=0.0099\right)$. The growth of weight relative to length was positive allometric $(b=3.107 ; 95 \% \mathrm{CI}$ : $3.06-$ 3.155 .

\section{Length frequency distribution:}

The monthly length frequency distribution (Fig. 5) of about 965 sample showed that the small fishes $(\leq 10 \mathrm{~cm})$; About one years old or less; were caught during January and September referring that the recruitment to the fishing ground occurs during these months.
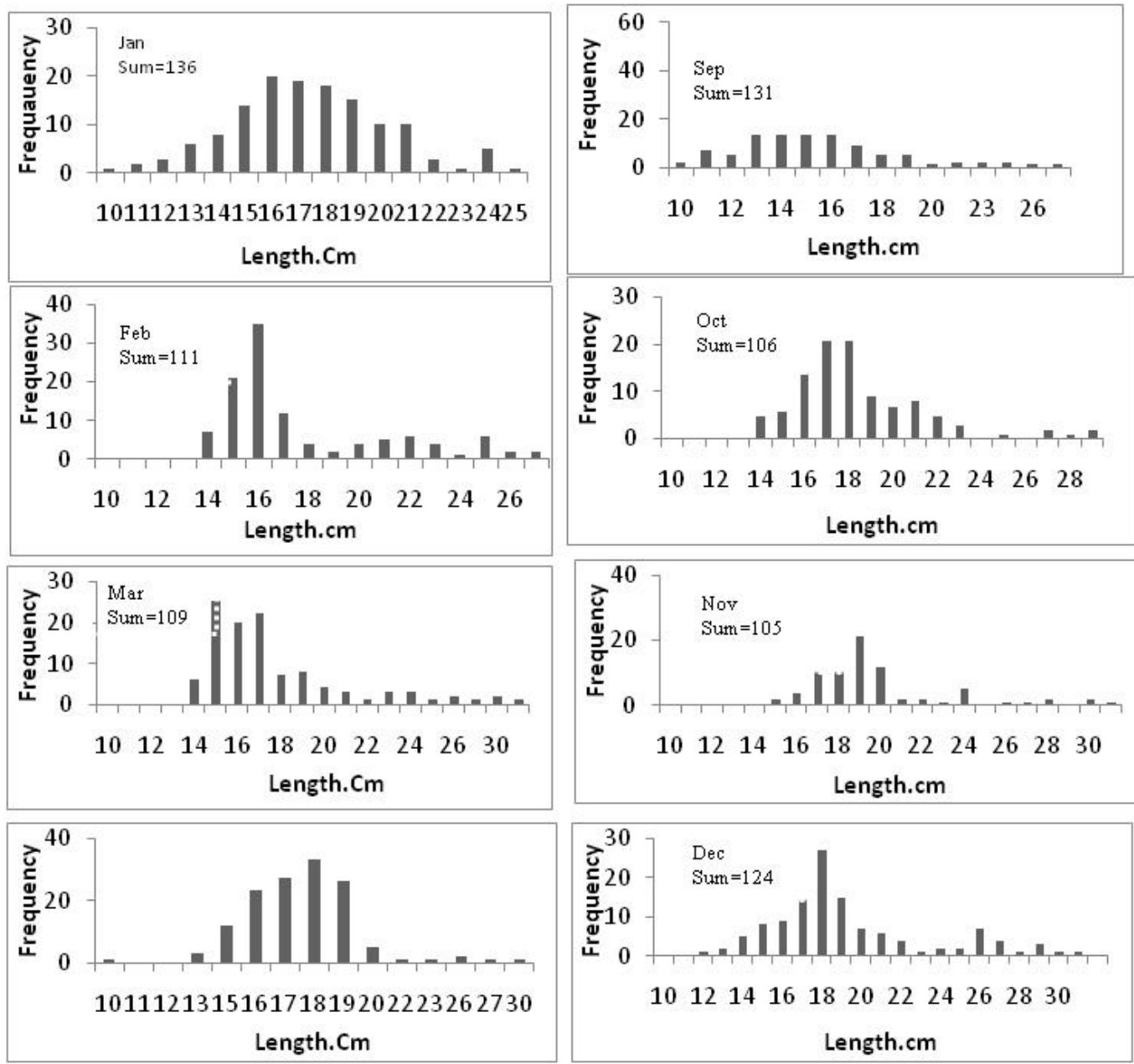

Fig. 5: Monthly length frequency distributions of Lizard fish (Saurida undosquamis).

\section{Age and growth:}

Age was determined by otolith reading of 310 specimens of Saurida undosquamis. Seven age groups were identified with mean lengths of 14.5, 19.2, 23, $26.4,29.5,32.1$, and 34.6 for the age groups from one to seven respectively (Table 1 \& Fig. 6). The maximum growth rate was recorded at the first year of life, and then the growth rate was gradually decreased with the increase of age. Age group II was dominating the catch.

The mean lengths at different ages were used for estimating the von Bertalanffy growth parameters. The estimated parameters were $\mathrm{L} \infty=51.252 \mathrm{~cm}, \mathrm{~K}=$ 0.131 year and $t_{o}=-1.45$ years. 
Table 1: Observed mean, maximum and minimum length with standard deviation of each age group of Saurida unosquamis estimated by otolith reading.

\begin{tabular}{|c|c|c|c|c|c|}
\hline Age group & Number of fish & Average & Min .L & Max .L & S.D. \\
\hline 1 & 46 & 14.5 & 10.4 & 19.6 & 1.7 \\
\hline 2 & 160 & 19.2 & 15.6 & 26.3 & 1.5 \\
\hline 3 & 47 & 23 & 19.4 & 28.6 & 2.0 \\
\hline 4 & 40 & 26.4 & 22.9 & 29.4 & 1.5 \\
\hline 5 & 11 & 29.5 & 25.8 & 30.8 & 1.3 \\
\hline 6 & 3 & 32.1 & 31.2 & 33.7 & 1.3 \\
\hline 7 & 3 & 34.6 & 32.4 & 36.1 & 1.9 \\
\hline
\end{tabular}

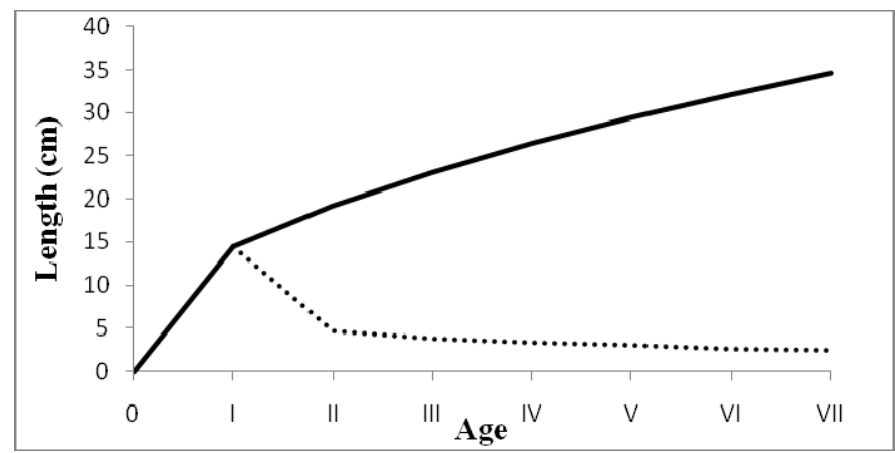

Fig. 6: Growth in length and length increment of Saurida undosquamis.

\section{Gonado- somatic index (GSI):}

Analysis of the seasonal variations of the GSI (Fig. 7) showed that the average values of gonad weight percentages increased substantially from autumn until spring. The maximum average values of GSI were recorded during spring for both males and females. This indicates that Saurida undosquamis has a prolonged spawning season from autumn to spring with an intensive spawning in spring.

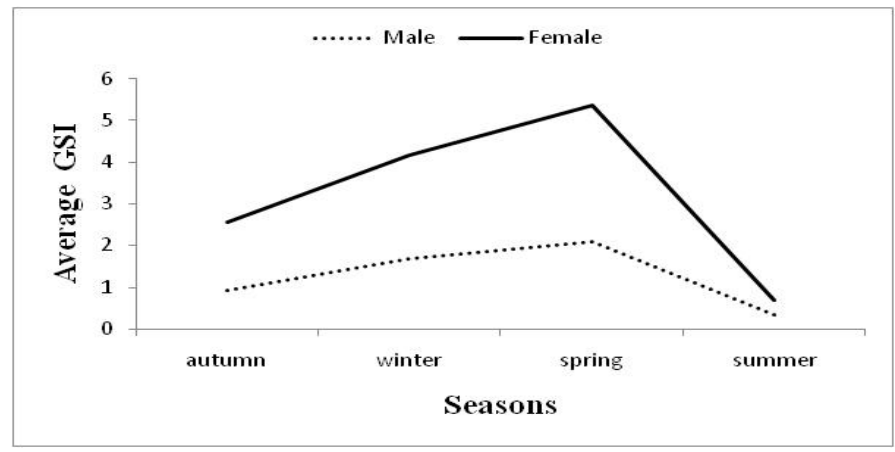

Fig. 7: Average values of males and females GSI of Saurida undosquamis

\section{Length at first sexual maturity:}

Analysis of the percentage of mature and immature fish in each length class showed that the minimum size of maturity was $10.5 \mathrm{~cm}$ for males and $11.5 \mathrm{~cm}$ for females, while the size at which $50 \%$ of fishes are mature were $15.0 \mathrm{~cm}$ for males (Fig. 8) and $15.5 \mathrm{~cm}$ for females (Fig. 9), thus all individuals over one years old were sexually mature. 


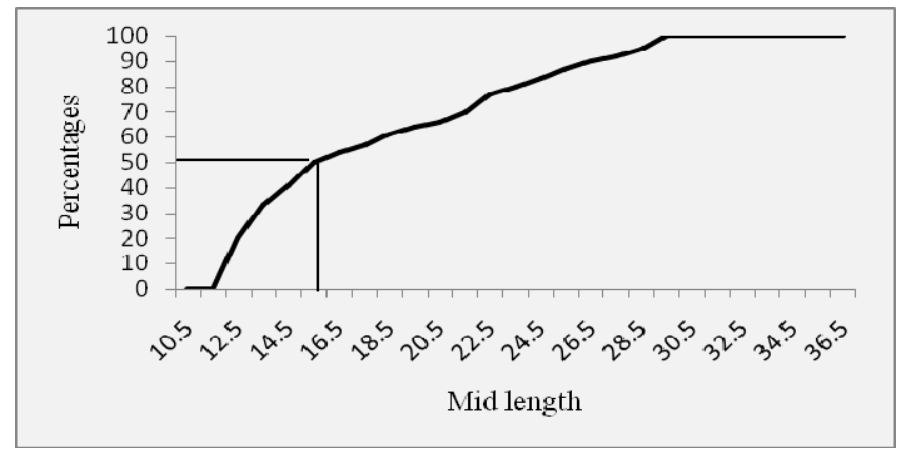

Fig. 8: The lengths of females Saurida unosquamis at 50\% sexual maturity.

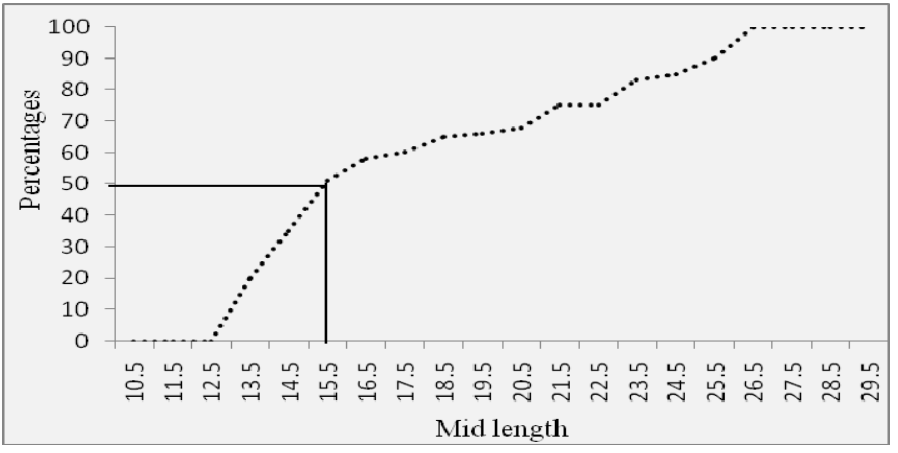

Fig. 9: The length of males Saurida undosquamis at 50\% sexual maturity.

\section{DISCUSSION}

Lizard fishes are one of the most economically important fish groups in the catch of the Gulf of Suez fishery. The annual total trawl catch and lizardfish catch landed at Atakka harbor during the last twelve years showed that the lizard fish catch represented an average of $28.7 \%$ of the total trawl catch.

The regression coefficient value (b) in total length-weight relationship equation of Saurida undosquamis showed that the growth of weight relative to length was almost positive allometric $(b=3.107)$. This result is in a good agreement with the previous recorded results as shown in Table (2) except that of Cicek \& Avsar (2011) who stated that the coefficient (b) is negative allometric $(<3)$.

Studies on age determination of Saurida undosquamis was carried out by using otolith. Results showed that it is a fast growing species where the fish attained about $40 \%$ of its length during the first year of life. Age group one represented about $14.8 \%$ of the fishery, while the most dominant age class was age group II with a percentage of 51.6\%. El-Ganainy (1992) estimated the life span of Saurida undosquamis in the Gulf of Suez as four years for males, and 6 years for females. The results of this study is in agreement with El-Ganainy (1992 and 2002); El-Halfawy et al. (2007); Amin et al. (2007); Çiçek and Avşar (2011) and Manaşırlı et al. (2011).

Results of the theoretical growth in length of Saurida undosqumis showed that $\mathrm{L} \infty=51.252 \mathrm{~cm}, \mathrm{~K}=0.131$ year and $\mathrm{t}_{0}=-1.45$ years. These results are in a good agreement with most of the previous studies in different localities, but there are some variation with some authors such as Ambak et al.(1986), Boonwanish (1991), Cicek 
et al. (2006), Gokce et al. (2007), Amin et al. (2007), El Halfawy et al. (2007), Metar (2011), Xuehui et al.(2012); these variations may be attributed to the different technique used in the age determination and the maximum recorded length in the different areas of study (Table 2).

Table 2: Growth parameters and Length weight constants for Saurid undosquamis collected from different regions compared with the present study.

\begin{tabular}{|c|c|c|c|c|c|c|c|c|}
\hline \multirow[t]{2}{*}{ Locality } & \multirow[t]{2}{*}{ Sex } & \multicolumn{3}{|c|}{ Growth parameters } & \multicolumn{2}{|c|}{$\begin{array}{l}\text { Length weight } \\
\text { constants }\end{array}$} & \multirow[t]{2}{*}{$\begin{array}{l}\text { Method of } \\
\text { ageing }\end{array}$} & \multirow[t]{2}{*}{ Source } \\
\hline & & $\mathrm{L}$ & $\mathrm{K}$ & $\mathrm{t}$ & $\mathrm{a}$ & $\mathrm{b}$ & & \\
\hline Malaysia & & 49.25 & 0.25 & & 0.0054 & 3.2421 & L.F. & Ambak et al. (1986) \\
\hline Thailand & & 41.8 & 0.6 & & & & L.F. & Boonwanish (1991) \\
\hline Gulf of Suez & M & 37.32 & 0.17 & -2.09 & 0.0027 & 3.27 & Otolith & El Ganainy (1992) \\
\hline & $\mathrm{F}$ & 55.56 & 0.11 & -2.13 & 0.0033 & 3.196 & Otolith & El Ganainy (1992) \\
\hline Japan & M & 44.2 & 0.162 & -1.238 & & & Otolith & Yoneda et al. (2002) \\
\hline & $\mathrm{F}$ & 51.8 & 0.16 & -0.948 & & & Otolith & Yoneda et al. (2002) \\
\hline Red Sea & M & 31.63 & 0.26 & -1.38 & 0.0017 & 3.319 & Otolith & El Ganainy (2004) \\
\hline & $\mathrm{F}$ & 41.72 & 0.17 & -1.53 & 0.0044 & 3.109 & Otolith & El Ganainy (2004) \\
\hline Turkey & & & & & 0.0039 & 3.165 & & Cicek et al. (2006) \\
\hline Turkey & & 42 & 0.51 & -0.29 & & & L.F. & Gokce et al. (2007) \\
\hline Gulf of Suez & M & 31.03 & 0.44 & -1.06 & 0.0042 & 3.131 & L.F. & Amin et al.(2007) \\
\hline Gulf of Suez & $\mathrm{F}$ & 35.56 & 0.26 & -1.059 & 0.003 & 3.167 & L.F. & El Halfawy et al. (2007) \\
\hline Taiwan & & 56.3 & 0.232 & -0.558 & & & Otolith & Jianguo et al. (2011) \\
\hline China & & & & & 0.0097 & 3.05 & & Wang et al.(2011) \\
\hline Turkey & & 41.57 & 0.118 & -1.895 & & & Otolith & Manasirli et al. (2011) \\
\hline India & & 34.6 & 0.87 & & & & L.F. & Metar (2011) \\
\hline Turkey & & 38.05 & 0.124 & -1.68 & 0.0083 & 2.879 & Otolith & Cicek \& Avsar (2011) \\
\hline China & & 34 & 0.52 & -0.3 & 0.0956 & 3.043 & L.F. & Xuehui et al. (2012) \\
\hline Gulf of Suez & & 51.25 & 0.131 & -1.45 & 0.004 & 3.107 & Otolith & Present study \\
\hline
\end{tabular}

The study of the seasonal variation of maturity stages and gonado somatic index of Saurida undosquamis revealed that this species is a spring spawner. These results are in a good agreement with El-Ganainy (1992). Kadharsha et al. (2013) found high gonado-somatic index values during October-December, suggesting spawning activity during this period. \{This species was found to be a total spawner in the Parangipettai waters (Kadharsha et al. (2013)

Knowledge of the length at first sexual maturity is important in fishery management. In the present study, the minimum size of sexual maturity of female of Saurida undosquaamis was $12.2 \mathrm{~cm}$ while the size at $50 \%$ maturity was $15.5 \mathrm{~cm}$; the minimum size at the sexual maturity of male was $13.5 \mathrm{~cm}$ while the size at $50 \%$ maturity was $15 \mathrm{~cm}$; These results agreed with those of EL-Ganainy (1992) who estimated the length at $50 \%$ of female by $15.5 \mathrm{~cm}$ and $14.5 \mathrm{~cm}$ for males in the Gulf of Suez.

\section{CONCLUSION}

The estimated length at first sexual maturity $15.0-16.0 \mathrm{~cm}$ and the observed length range of age group I is 10.4-19.6. The estimated length at first capture of the species is $18.0 \mathrm{~cm}$ (El-Ganainy (1992). This implies that juvenile individuals are the target of the fishery, and the stock dynamics of this species would be seriously affected. The high vulnerability of juvenile fish to capture by trawling would result in the reduction of the future yield of this species. Thus, the protection of juveniles is probably the key factor for the sustainability of the resource; through periodic spatial closure of the spawning and nursery areas. This may be achieved through the establishment of certain reserves in the Gulf of Suez to protect the spawning stock biomass, and then monitoring their effects as a management strategy. In this context, a map for the 
spawning and nursery grounds for all fishes in the Gulf of Suez should be prepared on the basis of sound biological research.

\section{REFERENCES}

Abdullah, M. (2002). Length-weight relationship of fishes caught by trawl off Alexandria, Egypt. Naga ICLARM Q., 25(1):19-20.

Ambak, M.A.; Mohsin, A. K. M. and Said, M.Z. (1986). Growth Characteristics of Lizard Fish (Fam: Synodontidae) in the South China Sea. Pertanika, 9 (2): 261-263.

Amin. A. M.; El-Halfawy, M. M. and Ramadan, A, M. (2007). Management and Reproduction of the Male Brushtooth Lizard fish Saurida undosquamis (Richardson) from Gulf of Suez, Egypt. Egypt. J. AquaL Biol \& Fish, 11(4): $149-162$.

Bertalanffy von, L. (1938). A quantitative theory of organic growth. Hum. Biol., 10 (2): 181-213.

Boonwanich, T. (1991). Population dynamics of Saurida elongata and $S$. undosquamis (Synodontidae) in the southern Gulf of Thailand. Fish. Byte, 9(1): 23-27.

Chen, P. (2003). Optimum catchable size of 17 fish species in southwestern shelf of Nashua islands and optimum trawl mesh size for multiple fishes. J. Fish. Sci. China, 10 (1): 41-45.

Cicek, E.; Avsar, D.; Yeldan, H. and Ozutok, M. (2006). Length-weight relationships for 31 teleost fishes caught by bottom trawl net in the Babadillimani Bight (northeastern Mediterranean). J. Appl. Ichthyol., 22: 290-292.

Çiçek, E. and Avşar, D. (2011). Growth, Mortality and Spatial Distribution of Brushtooth Lizard fish, Saurida undosquamis (Richardson, 1848), Inhabiting the Karataş Coasts (Iskenderun Bay, Northeastern Mediterranean). Acta zool. bulg., 63 (1): 97-103.

Edelist, D. (2012). New length-weight relationships and Lmax values for fishes from the Southeastern Mediterranean Sea. J Appl Ichthyol., pp. 1-5.

El-Ganainy, A. A (1992). Biological Studies on Lizard Fishes, Saurida undosquamis (Pisces: Synodontidea) From the Gulf of Suez. M. Sc. Thesis, Faculty of Science, Ain Shams University, Cairo. Egypt.

El-Ganainy, A. A (1997). Population Dynamics of Lizard Fishes (Synodontidae) From the Red Sea. Ph.D. Thesis, Faculty of Science, Suez Canal University, Ismailia. Egypt.

El-Ganainy, A. A. (2002). Assessment of the lizard fish Saurida undosquamis (Richardson) fishery in the Gulf of Suez, Red Sea." Bull. Nat. Inst.

El-Ganainy, A. A. (2004). Biological characteristic and fishery assessment of the lizard fishes Saurida imdosquamis from the Red Sea, Egypt". Egypt. J. Aquatic. Boil. \& Fish., 8(2):93-113.

EL-Greisy, Z. A. B (2005). Reproductive Biology and Histology of Male Brushtooth Lizardfish Saurida undosquamis (Richardson), Family: Synodontidae, From the Mediterranean Coast of Egypt. Egy, J. of Aqu. Res. Issn 1110-0354 Vol. 31, 1.

El-Halfawy, M. M.; Amin, A. M. and Ramadan, A. M. (2007). Growth and Reproduction of Female Brushtooth Lizardfish Saurida undosquamis (Richardson) from the Gulf of Suez, Egypt., 24(1-2):143-148.

Escalona, V. H. C.; Peterson, M. S.; Davila, L. C. and Rejon, M. Z. (2005). Feeding habits and tropic morphology of inshore lizardfish (Synodus foetens) on the 
central continental shelf off Veracruz, Gulf of Mexico. J. Appl. Ichthyol. 21: $525-530$.

Faltas, S. (1993). Studies of the biology of lizard fish (family: Synodontidae) in the Egyptian Mediterranean waters. Ph. D. thesis, Alex. University.

Ford, E. (1933). An account of the herring investigations conducted in Plymouth during the years from 1924 to1933. J. Mar. Biol. Assoc. U.K., 19:305- 384.

Gookce, G.; Sangun, L.; Ozbilgin, H. and Bilecenoglu, M. (2007). Growth and mortality of the brushtooth lizardfish (Saurida undosquamis) in Iskenderun Bay (eastern Mediterranean Sea) using length frequency analysis. J. Appl. Ichthyol. 23:697-699.

Gulland, J. A. (1971). The fish resources of the ocean. FAO Fish Tech. Pap., (97): 425pp.

Gunderson, J. A. (1993). Surveys of fisheries resources. John Wily and sons, Inc. New York.

Ismen, A. (2003). Maturity and fecundity of lizard fish (Saurida undosquamis Richardson, 1848) in Iskenderun Bay (Eastern Mediterranean). Turk. J. Zool., 27: 231-238.

Kadharsha, K.; Mohanchander, P.; Lyla, P.S. and Khan, S. A. (2013). Feeding and reproductive biology of Saurida undosquamis (Richordson1848) from Parangipettai Coast, Southeast Coast of India. Pak.J. biol Sci., 16(22):14791487.

King, M. (1995). fisheries biology :assessment and management " fishing new Books Osney Mead, Oxford, England, 314p.

Letourneur, Y. M. Kulbicki and Labrosse, P. (1998). Length-weight relationships of fish from coral reefs and lagoons of New Caledonia, southwestern Pacific Ocean: an update. Naga ICLARM Q., 21(4):39-46.

Manaşırlı, M.; Avşar, D. and Yeldan, H. (2011). Population Dynamical Parameters of Brushtooth Lizard Fish [Saurida undosquamis (Richardson, 1848)] from the Northeastern Mediterranean Coast of Turkey. Ege. J. Fish. Aqua. Sci., 28(4):111-115.

Metar, S.; Chakraborty, K. S.; Jaiswar, K. A.; Sudheesan, D. and Sajina, A. M. (2011). growth and stock assessment of saurida undosquamis (richardson1848) from Mumbai coast India, Indi. j. marine Sci., 40 (1): 59-61.

Pauly, D. (1983). Some simple methods for the assessment of tropical fish stocks. FAO Fish. Tech. Pap., (234): 52p.

Pauly, D. and Gayanilo, F. C. (1996). Estimating the parameters of length-weight relationships from length-frequency samples and their weights. p. 136". In D. Pauly and P. Martosubroto (eds.) Baseline studies of biodiversity: the fish resource of western Indonesia. ICLARM stud. Rev., 23 pp.

Rahimibashar, M. R.; Alipour, V.; Hamidi, P. and Hakimi, B. (2012). Biometric Characteristics, Diet and Gonad Index of Lizardfish (Saurida tumbil, Bloch 1795) in North of the Persian Gulf. World, J, Fish and Marine Sci., 4 (1): 01-06.

Sanders, M. J.; Kedidi, S. M. and Hegazy, M. R. (1984). Catches, fishing efforts, catches per fishing effort and fishing locations for the Gulf of Suez and Egyptian Red Sea coast trawl fishery during 1979 to 1982. FAO RAB/ 81/002, 54 pp.

Shenouda, T.S. (1969). Biological studies on Saurida undosquamis (Richardson) from the Gulf of Suez. M. Sc. Thesis, Fac. Sci., Cairo Univ., 179pp.

Shenouda, T.S. (1976). Some biological aspects of Saurida undosquamis (Richardson), family Synodontidae in the Red and Mediterranean Seas. Ph. D. Thesis, Moscow Univ. USSR., 158p. 
Walford, L. A. (1946). A new graphic method of describing the growth of animals. Biol. Bull. Mar. Biol., 90 (2):141-147.

Wang, X. H.; Qiu, Y. S.; Zhu, G. P.; Du. F. Y.; Sun. D. R. and Huang. S. L (2011) Technical contribution Length-weight relationships of 69 fish species in the Beibu Gulf, northern South China Sea. J. Appl. Ichthyol., 27: 959-961.

Xuehui, W. A. N. G.; Yongsong, Q. I. U.; Feiyan, D.U.; Zhaojin, L. I. N.; Dianrong, S. U. N. and Shuolin, H.U. A. N. G. (2012). Population parameters and dynamic pool models of commercial fishes in the Beibu Gulf, northern South China Sea. Chinese, J, Oceanolo, Limnolo, 30 (1):105-117.

$\mathrm{Xu}, \mathrm{G} . ;$ Zheng, W. and Huang, O. (1994). Atlas of the fishes and their biology in Daya Bay. Anhui Scientific and Technical Publishers, P. R. O. C., 311 pp.

Yoneda. M.; Sakai, T.; Tokimura, M.; Horikawa, H. and Matsuyama, M. (2002). Age and growth of the lizardfish Saurida sp. 1 in the East China Sea using otolith ring marks. Fisheries Research, 55: 231-238.

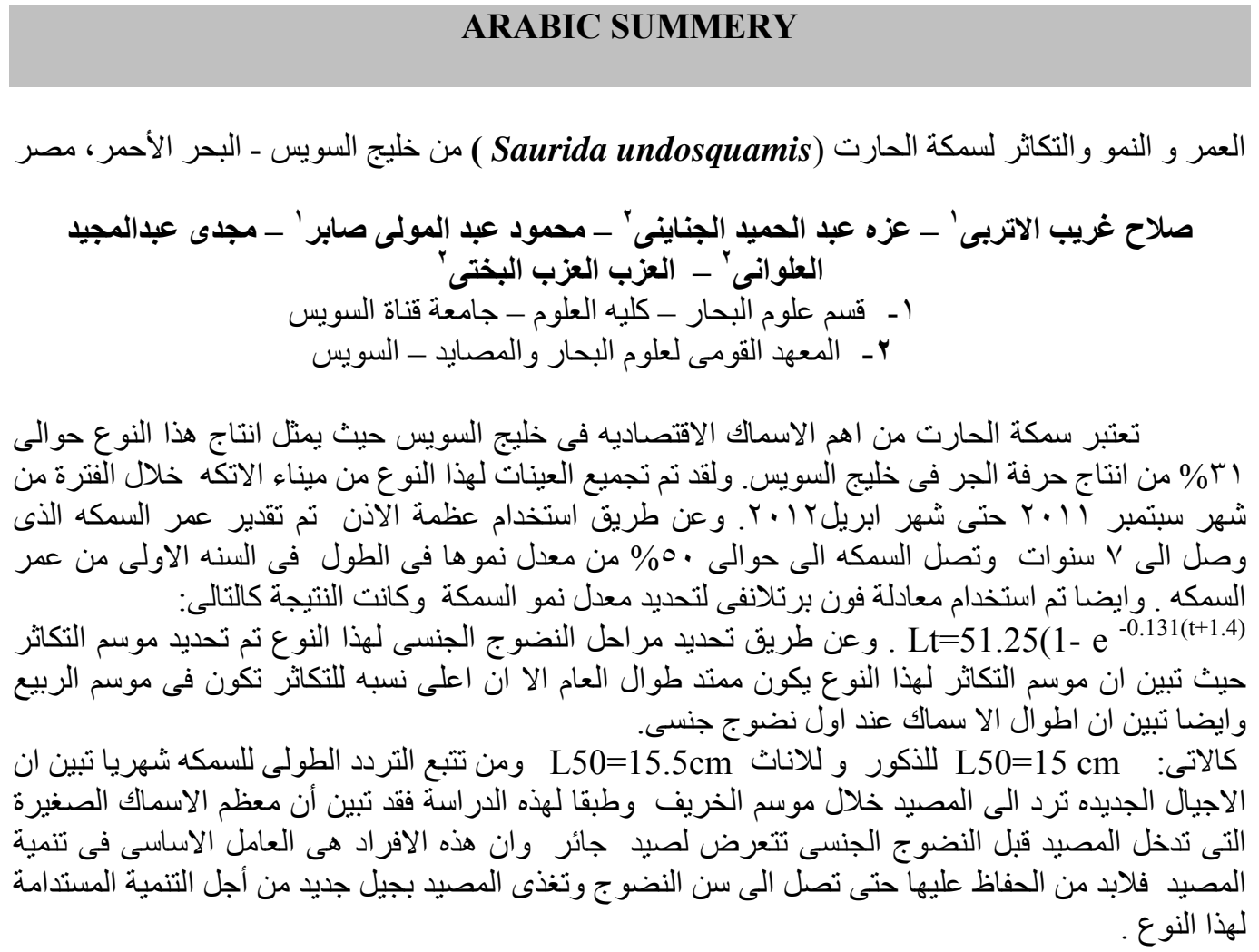

